\section{Journal of Technology Law \& Policy}

Volume XV - Spring 2015

ISSN 2164-800X (online)

DOI $10.5195 /$ tlp.2015.172

http://tlp.law.pitt.edu

\title{
Weaponized Police Drones and Their Effect on Police Use of Force
}

Kyle Stelmack

\section{(c) EY-NC-ND}

This work is licensed under a Creative Commons Attribution-Noncommercial-No Derivative Works 3.0 United States License.

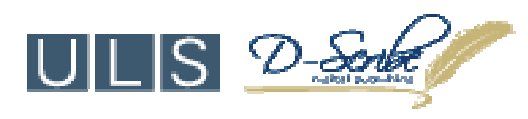

This site is published by the University Library System of the University of Pittsburgh as part of its DScribe Digital Publishing Program and is cosponsored by the University of Pittsburgh Press. 


\title{
Weaponized Police Drones and Their Effect on Police Use of Force
}

\author{
Kyle Stelmack ${ }^{*}$
}

For nearly 25 years, claims of police use of excessive force during the "seizure" of a person have been analyzed under the "reasonableness" standard of the Fourth Amendment. ${ }^{1}$ On thousands of occasions, courts have looked at the "totality of the circumstances" surrounding these cases and have taken into great consideration the tense and changing environments in which police find themselves, as well as the need for officers to make quick decisions under such circumstances. $^{2}$ How then, would a court react to an excessive force claim where the police apply the force, but are not physically present when the force is applied? Armed police drones present exactly this dilemma.

Drones have been put to use by federal, state, and local law enforcement agencies throughout the country, primarily for surveillance purposes. ${ }^{3}$ Although these police drones are not equipped with any type of weapon, many are capable of being armed with such technology and several weaponized police drones have been developed. ${ }^{4}$ Drones capable of deploying tasers, pepper spray, paint balls, and plastic bullets have already been constructed, ${ }^{5}$ and law enforcement's future implementation of this type of technology is not outside the realm of possibility. ${ }^{6}$ Widespread use of these types of police drones could significantly alter the way that courts typically review use of force claims. This is true not only because they remove the officer from the tense environment that has been so influential in past

${ }^{*}$ J.D. candidate, University of Pittsburgh School of Law, May 2016. The author would like to thank Mom, Dad, and Tyler for all of their love and encouragement.

${ }^{1}$ Graham v. Connor, 490 U.S. 386, 395 (1989).

${ }^{2}$ Seth W. Stoughton, Policing Facts, 88 TUL. L. REV. 847, 864-65 (2014).

${ }^{3}$ American Civil Liberties Union, Protecting Privacy From Aerial Surveillance: RECOMMENDATIONS FOR GOVERNMENT USE OF DRONE AIRCRAFT 6-7 (2011) [hereinafter ACLU Domestic Drone Report].

${ }^{4}$ See Skunk Riot Control Copter, DESERT WOLF, http://www.desert-wolf.com/dw/products/ unmanned-aerial-systems/skunk-riot-control-copter.html; Susanna Kim, Texas Start-up Tasers Intern Via Stun-Copter to Spark Discussion About Tech and SXSW, ABC NEwS (Mar. 10, 2014), http://abcnews.go.com/Business/intern-tasered-drone-sxsw-explains-feels-zapped/story?id=22848505.

${ }^{5} I d$.

${ }^{6}$ ACLU Domestic Drone Report, supra note 3, at 11.

Journal of Technology Law \& Policy

Volume XV - Spring 2015 • ISSN 2164-800X (online)

DOI 10.5195/tlp.2015.172 • http://tlp.law.pitt.edu 
excessive use of force decisions, but because they also add new concerns to the analysis that could present substantial challenges for the courts. ${ }^{7}$

The following Article will take a closer look at this new type of technology and how it would affect a decision in an excessive force case. Section I will describe what a drone is and the capabilities of CUPID and the Skunk Riot Control Copter. Section II is a discussion regarding the history of the use of force standard and the issues that it has created. Section III moves onto a discussion concerning the new factors and concerns armed police drones raise and how they could affect the current reasonable use of force precedent. Section IV suggests a standard allowing for the use of force by a UAS only in situations where it is reasonable to prevent an imminent threat to public safety.

\section{What Is AN UnMANNED AERIAL SYSTEM?}

An unmanned aerial system ("UAS") is a "system whose components includes the necessary equipment, network, and personnel to control an unmanned aircraft." ${ }^{8}$ These systems normally include three basic components: the unmanned aircraft, the "ground control system," and the operator. ${ }^{9}$ Although many unmanned aircraft can be pre-programmed to fly autonomously, this Article will focus on drones controlled remotely, using a ground control station by an operator. Thus, the UAS that is the topic of this Article would include the unmanned aircraft, the control system, and a police officer (i.e., operator) that would be controlling the aircraft and deciding whether or not to deploy the weapons.

In order to understand how a UAS could bring about an excessive force claim, it is essential to first grasp the capabilities of the unmanned aircraft, or drone. The Department of Defense defines drones as "powered aerial vehicles sustained in flight by aerodynamic lift ... and guided without a flight crew." 10 This is a very basic definition that encompasses hundreds of different "unmanned aerial vehicles." $"$ Drones can come in a variety of shapes and sizes ranging from the

\footnotetext{
${ }^{7}$ Peter Olsthoorn \& Lamber Royakkers, Risks and Robots—Some Ethical Issues, available at http://isme.tamu.edu/ISME11/Olsthoorn-ISME2011.pdf.

${ }^{8}$ Suraj G. Gupta, Review of Unmanned Aircraft System (UAS), 2 InT'L J. OF ADVANCED RESEARCH IN COMPUTER AND ENGINEERING TECH. 1646 (2013), available at http:// www.uxvuniversity.com/wp-content/uploads/2014/04/Review-of-Unmanned-Aircraft-System-UAS.pdf.

${ }^{9} \mathrm{Id}$.

${ }^{10}$ U.S. DEP'T OF DEFENSE, Unmanned Aerial Vehicles (June 3, 2003), http://www.defense.gov/ specials/uav2002/.

${ }^{11}$ Id.

USE OF F OR C E A N D W E P O N I Z D P O L I C E D R O N E S

Volume XV - Spring 2015 • ISSN 2164-800X (online)

DOI 10.5195/tlp.2015.172 • http://tlp.law.pitt.edu
} 
dimensions of a small airplane to that of a hummingbird. ${ }^{12}$ Historically, for both military and police, the most common use of drones has been for surveillance, ${ }^{13}$ due to their capacity for housing a wide range of surveillance technology, including high powered lenses, GPS, automated object detection, and gigapixel cameras. ${ }^{14}$

\section{A. Weaponized Police Drones}

Although it appears unlikely that police drone weaponry will ever rise to the lethal levels employed by the military, the idea of non-lethal weapons systems being attached to police drones is not out of the realm of possibility, and, in fact, has already been seriously contemplated. ${ }^{15}$ In 2007, Michael Buscher, the CEO of Vanguard Defense Industries, which had provided a drone to a Houston area law enforcement agency, stated that the drones provided were designed to carry weapons. ${ }^{16}$ Buscher went on to say that these "less lethal systems" for police could fire tasers and beanbags known as "stun batons." agency made it clear that this drone would not carry weapons, ${ }^{18}$ but the capability exists, and other manufacturers have been able to demonstrate what such capabilities look like.

Desert Wolf, a South African company, and Chaotic Moon, a Texas corporation, have each developed a drone that is capable of deploying forms of non-lethal weaponry. ${ }^{19}$ Although neither has been distributed to an American law enforcement agency, ${ }^{20}$ they are both useful in exemplifying how this technology could be used.

Desert Wolf's design, known as the Skunk Riot Control Copter, features a system that includes four high capacity paint ball barrels each capable of firing 20

\footnotetext{
${ }^{12}$ ACLU Domestic Drone Report, supra note 3, at 2-3.

${ }^{13}$ See id. at 1; Unmanned Aerial Vehicles, supra note 10.

${ }^{14}$ Chris Schlag, The New Privacy Battle: How the Expanding Use of Drones Continues to Erode our Concept of Privacy and Privacy Rights, 13 U. PITT. J. TECH. L. \& POL'Y 1, 7-8 (2013).

${ }^{15}$ Id. at 22; Roy Carroll, Drone Warfare: A New Generation of Deadly Unmanned Weapons, THE GuARDIAN (Aug. 2, 2012, 11:40 PM), http://www.guardian.co.uk/world/2012/aug/02/drone-warfareunmanned-weapons.

${ }^{16}$ Stephen Dean, New Police Drone Near Houston Could Carry Weapons, CLICK2Houston (Nov. 10, 2011, 1:51 PM), http://www.click2houston.com/news/New-Police-Drone-Near-HoustonCould-Carry-Weapons/4717922.

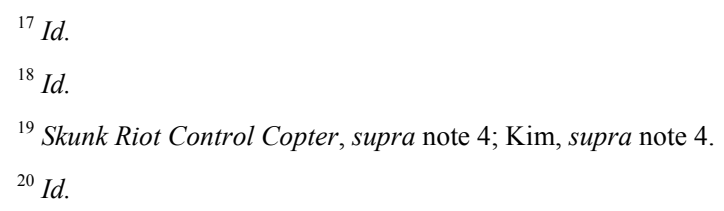

Journal of Technology Law \& Policy
}

Volume XV - Spring 2015 • ISSN 2164-800X (online)

DOI 10.5195/tlp.2015.172 • http://tlp.law.pitt.edu 
balls per second. ${ }^{21}$ These balls can be filled with pepper spray, colored dye, or solid plastic bullets, and the device is also equipped with "blinding lasers." 22 At its maximum capacity the Skunk Riot Control Copter can fire up to 80 balls per second and, as is stated on the company's website, can stop "any crowd in its tracks. ${ }^{23}$ The drone is also equipped with a thermal camera, full HD color camera, as well as a full telemetry data link and long range control link. ${ }^{24}$ The control system for the drone allows the user to have full control over the planning and execution of the drone's functions, includes a real-time video link, and, importantly for the purposes of this Article, records full flight logs and mission notes, which include a video and audio recording of the operator while in use. ${ }^{25}$

Unlike Desert Wolf, whose goal it is to distribute the Skunk Copter commercially, Chaotic Moon designed their drone to demonstrate the capabilities of this type of technology, and the low cost at which it can be produced. ${ }^{26}$ The device, called the Chaotic Unmanned Personal Intercept Drone, or CUPID, was built with many "common, off the shelf parts," and has the capability to shoot a barbed wire taser that could deliver up to 80,000 volts. ${ }^{27}$ The taser was able to subdue a 26-year-old male intern, on who it was tested, and had a safety mechanism in place that would allow for a manual override of the taser.

The capabilities of both of these devices are comparable to the described capabilities of the drone manufactured by Vanguard Defense Industries, and in use by a law enforcement agency outside of Houston, but not yet implemented. While there are no drones in the United States operating with these non-lethal weapon systems, it is clear that this is not only possible, but also becoming an attractive and inexpensive option for law enforcement. ${ }^{28}$ With that said, there is a significant chance that drones will move beyond strictly surveillance uses and move into intervention in situations on the ground. ${ }^{29}$

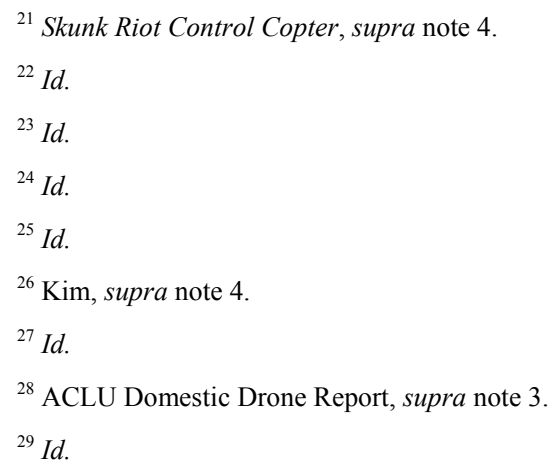


It may be difficult to imagine how a UAS could intervene in a ground situation, and until it is put to use we will be unable to know for sure. However, by examining the technology and its capabilities, it is possible to predict how police departments may utilize them. The first and perhaps most obvious application is for crowd control, and in fact the Skunk Riot Control Copter is marketed for precisely this purpose. ${ }^{30}$ In these situations, the drones would likely be used around and within large crowds while the operator monitors the situation from a safe distance. The police could then use the weaponry available on the UAS to control the crowd's movement, employing pepper spray or rubber bullets to prevent the crowd from moving past certain points. It is also quite possible for these drones to target individuals within the crowd, firing a taser or stun-baton to halt an individual's movement until officers arrive.

Although crowd control is the most obvious use for a UAS, it is possible to imagine situations where it could be applied to individualized setting outside of a large crowd. Imagine perhaps a situation in which the police receive a report of a suspicious person or suspicious activity occurring in a public area. Before an officer is dispatched, a UAS could be utilized to arrive on the scene first, allowing the operator to survey the situation before the officers arrive on the scene. Using the audio equipment, the officer could announce the police presence, follow the individual if he or she attempts to flee, and, if the situation calls for it, use the weaponry to prevent the individual from moving any farther or causing any person harm.

It is important to remember that these situations are hypothetical, and there is no way to truly know how a particular police department would choose to use a UAS in a crowd control or individual arrest situation. These are, however, examples of the more likely situations in which a UAS could be deployed and cause a seizure of an individual, and thus lead to the problems that will be discussed below.

\section{LEGAL HISTORY OF THE “USE OF FORCE” DOCTRINE}

Before exploring the legal background of police use of force, it is important to remember that law enforcement's use of a UAS against an individual represents the final link in a chain of events - a chain that gives rise to numerous legal and social concerns that are not at-issue in this Article. And despite the fact that several law enforcement agencies across the country have already purchased non-weaponized

\footnotetext{
${ }^{30}$ Skunk Riot Control Copter, supra note 4.
}

Journal of Technology Law \& Policy

Volume XV - Spring 2015 • ISSN 2164-800X (online)

DOI 10.5195/tlp.2015.172 • http://tlp.law.pitt.edu 
drones, deployment of these devices remains a hotly contested issue. ${ }^{31}$ Their application for surveillance purposes have raised significant Fourth Amendment concerns involving illegal searches, while state legislatures scramble to set limits on their use. ${ }^{32}$ Assuming legislatures do allow the police to deploy an armed UAS, there will have to be significant discussions as to how to best train operators to ensure that their instruction on constitutional standards is adequate. ${ }^{33}$ Only after these preliminary issues are addressed will an encounter between a police UAS and an individual necessitate a determination of whether or not reasonable force was used.

Regardless, drones carrying non-lethal weapons pose an interesting problem. If law enforcement agencies were to deploy such drones during the course of an arrest, they could potentially be used to subdue the suspect. In this type of situation it is no longer a police officer who is physically applying force to a subject, but instead a drone operator, who could be miles away from the situation, applying the force through the use of a drone. How then, in a situation where a drone operator uses the drone's weaponry to "stop a suspect in their tracks,"34 would a court determine if the force was "reasonable"? To answer this, one must first look to the standards already set regarding the use of force.

Excessive force claims against police officers typically arise under 42 U.S.C. $\S 1983 .{ }^{35}$ In order for a plaintiff to be successful in a $\S 1983$ claim, he or she must show that the police officer, in using force, deprived the plaintiff of a protected constitutional or statutory right. ${ }^{36}$ In reviewing these cases, courts first determine the specific constitutional right at-issue, and then judge the claim in reference to the "specific constitutional standard, which governs that right." ${ }^{37}$ The U.S. Supreme Court has made clear that, in the course of an arrest or investigatory stop, the

${ }^{31}$ Somini Sengupta, Rise of Drones in U.S. Drives Efforts to Limit Police Use, N.Y. TIMES (Feb. 15, 2013), http://www.nytimes.com/2013/02/16/technology/rise-of-drones-in-us-spurs-efforts-tolimit-uses.html?pagewanted=all\&_r=0.

${ }^{32} I d$.

${ }^{33}$ See Editorial Board, Deadly Force in Philadelphia, N.Y. Times (Mar. 26, 2015), http:// www.nytimes.com/2015/03/26/opinion/deadly-force-in-philadelphia.html?hp\&action=click\&pgtype= Homepage \&module $=\mathrm{c}$-column-top-span-region\&region $=\mathrm{c}$-column-top-span-region \&WT.nav $=\mathrm{c}-$ column-top-span-region\&_r $=0$ (discussing the Justice Department suggestions regarding training on the use of force in the Philadelphia Police Department).

\footnotetext{
${ }^{34}$ See Skunk Riot Control Copter, supra note 4.

${ }^{35} 42$ U.S.C. $\$ 1983$ (2012).

${ }^{36} \mathrm{Id}$.

${ }^{37}$ Graham v. Connor, 490 U.S. 386, 394 (1989).
} 
excessive force claim normally invokes the Fourth Amendment, ${ }^{38}$ which guarantees people a right "to be secure in their persons ... against unreasonable ... seizures. ${ }^{" 39}$ Thus, in these situations the claim will be analyzed under the "reasonableness standard" of the Fourth Amendment. ${ }^{40}$

Before performing any reasonableness analysis, it is first necessary to determine whether or not a seizure of the person has actually occurred. The Supreme Court tells us that for a seizure of a person to occur it is necessary for there to be some "show of authority" by police, such that a "reasonable person would have believed that he was not free to leave." component, this show of authority is not alone sufficient to constitute a seizure, and requires with it either a use of physical force by police or submission by the suspect to that authority. ${ }^{42}$

Applying this two-prong test to a UAS, it is likely that the deployment of these weapons would indeed amount to a seizure under the Fourth Amendment. Beginning first with a "show of authority," although no police officer would be physically present, the drones themselves can be equipped with audio equipment, making it possible for the operator to communicate to the suspects, and relaying to them information demonstrative of police authority. Further, the nature of the nonlethal weaponry not only shows law enforcement's authority to the point where an individual's movement is restrained, but can also constitute the additional physical force needed to prove that a seizure has occurred. Several cases from various jurisdictions have found that the intentional use of pepper spray against groups of protesters or individuals has constituted a seizure under the Fourth Amendment. ${ }^{43}$ Similarly, the use of a taser against an individual constitutes a seizure for Fourth Amendment purposes. ${ }^{44}$

Once it has been determined that a seizure has occurred, it is then appropriate to shift focus to the reasonableness standard of the Fourth Amendment. This

${ }^{38} I d$. at 395.

${ }^{39}$ U.S. CONST. amend. IV.

${ }^{40}$ Graham, 490 U.S. at 395.

${ }^{41}$ California v. Hodari, 499 U.S. 621, 627-28 (1991) (citing United States v. Mendenhall, 446 U.S. 544, $554(1980))$.

${ }^{42}$ Id. at $626-27$.

${ }^{43}$ See Headwaters Forest Def. v. Cnty. of Humboldt, 276 F.3d 1125, 1130 (9th Cir. 2002) ("It would be clear to a reasonable officer that using pepper spray against the protesters was excessive under the circumstances."); Marbet v. City of Portland, 2003 WL 23540258, at *10 (D. Or. Sept. 8, 2003) (stating that use of pepper spray to control protester movement constituted a seizure).

${ }^{44}$ See Kijowski v. City of Niles, 372 Fed. Appx. 595, 598-99 (6th Cir. 2010).

Journal of Technology Law \& Policy

Volume XV - Spring 2015 • ISSN 2164-800X (online)

DOI 10.5195/tlp.2015.172 • http://tlp.law.pitt.edu 
standard requires a balancing test, where on one hand the court considers the "nature and quality of the intrusion on the individual's Fourth Amendment rights," and on the other it takes into consideration the "importance of the governmental interests alleged. ${ }^{, 45}$ During an arrest this reasonableness standard plays out over the course of two different stages. First, it is reasonable for police to seize an individual when there exists probable cause or a reasonable suspicion that criminal activity is afoot. ${ }^{46}$ The Court has held however that "the reasonableness of a particular seizure depends not only on when it is made, but also on how it is carried out." ${ }^{\text {"47 }}$ Thus, not only must the seizure itself be reasonable but the force used in carrying out the seizure must also be reasonable. ${ }^{48}$ Although it has long been settled that during the course of an arrest some form of force or coercion will be necessary, ${ }^{49}$ it has become increasingly difficult to determine what amount of force is appropriate. ${ }^{50}$

Tennessee v. Garner was one of the first instances in which the Supreme Court dealt directly with the question of what amount of police force is reasonable during the course of an arrest. ${ }^{51}$ In Garner, Memphis police officers, responding to a burglary, encountered Edward Garner standing outside the home. ${ }^{52}$ The officers stated that they did not see Garner with a weapon, nor did they believe he was armed. ${ }^{53}$ Upon ordering him to halt, Garner began to climb over a backyard fence at which point, fearing that he would elude capture, was shot by the responding officers. ${ }^{54}$ Although the officers were acting under a Tennessee statute that allowed any force necessary to affect an arrest, the Supreme Court held that the use of deadly force in this situation was unreasonable. ${ }^{55}$ The Court was careful to articulate that it was the facts of this case that made the seizure, specifically the taking of Garner's life, unreasonable, and that when determining the reasonableness of a seizure for Fourth Amendment purposes it is important to

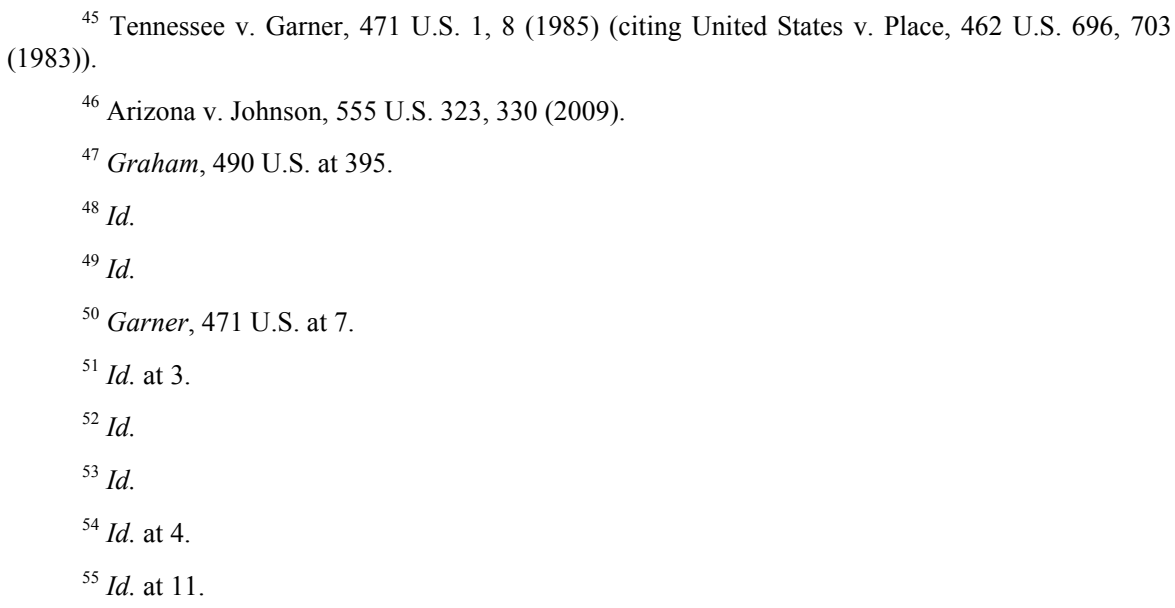

US E O F F R C E A N D W A P O N I E D P O L I C E D R O N E S

Volume XV - Spring 2015 • ISSN 2164-800X (online) DOI 10.5195/tlp.2015.172 • http://tlp.law.pitt.edu 
consider whether "the totality of the circumstances justified a particular ... seizure. $" 56$

In Garner, this "totality of the circumstances" approach was confined to a situation where the use of force was lethal. ${ }^{57}$ Four years later, in Graham v. Connor the Court was asked to apply this approach to a use of non-lethal force. ${ }^{58}$ The Graham Court attempted to clarify the "totality of the circumstances" analysis dictated in Garner by proposing several factors that should be taken into consideration, such as the severity of the crime, whether the suspect is posing an immediate threat to the officers, and whether he is actively resisting or fleeing from arrest. ${ }^{59}$ The Court also emphasized that this inquiry is an objective one, and must be looked at from the perspective of the officer at the scene, not in hindsight and also disregarding any underlying motivation or intent of the particular officer. ${ }^{60}$ Finally, the Court emphasized that in determining the reasonableness of the seizure the court must give "allowance for the fact that police officers are often forced to make split-second judgments - in circumstances that are tense, uncertain, and rapidly evolving - about the amount of force that is necessary in a particular situation. ${ }^{, 61}$ This language, on which courts have relied heavily, will be pertinent to the introduction of weaponized police drones.

The most recent Supreme Court decision concerning police force, and one that could have a significant influence on decisions involving drones, is the case of Scott v. Harris. ${ }^{62}$ In Scott, a ten-mile high-speed car chase, initiated by the defendant, was brought to an end when Officer Scott used the bumper of his patrol car to force Harris off the road, resulting in serious injuries. ${ }^{63}$ The Court, per Justice Scalia, determined that Scott's actions were reasonable under the Fourth Amendment, and in doing so reaffirmed that there is not bright-line rule for these situations and that courts must "slosh [their] way through the factbound morass of 'reasonableness." ${ }^{64}$ What is interesting from the Court's decision in Scott, and what could be highly influential in any case involving police drones, is that the

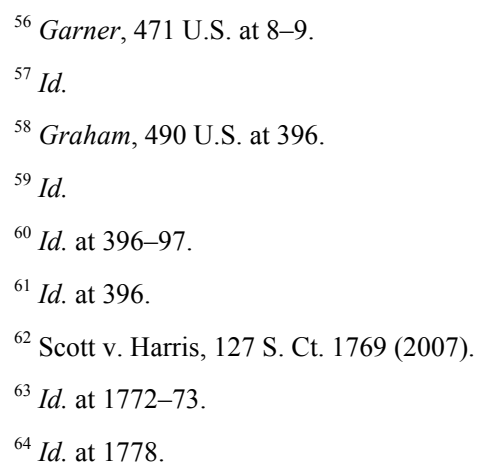

Journal of Technology Law \& Policy

Volume XV - Spring 2015 • ISSN 2164-800X (online)

DOI 10.5195/tlp.2015.172 • http://tlp.law.pitt.edu 
Court reached its conclusion in large part by viewing a video recording of the entire incident. ${ }^{65}$ In fact, the presence of this video led the Supreme Court to make its own factual determination about the events that led to Officer Scott's use of force, enabling the Court to make a reasonableness decision based off these factual determinations. ${ }^{66}$

It is clear from these decisions that the determination of whether a use of force is excessive is volatile, and without a bright-line rule it is difficult to determine how courts will decide individual cases. ${ }^{67}$ However, there is no indication that this standard will change before any type of weaponized drone is deployed on the street. Therefore, this standard, at least initially, will be used for any type of excessive force claims involving drones.

\section{The Consideration of New Psychological Factors}

The Graham court, in analyzing a totality of the circumstances approach laid out several factors that should be taken into account when determining whether the police used reasonable force ${ }^{68}$ Although these factors are noticeably absent from the Court's decision in Scott, ${ }^{69}$ their description of reasonableness as a "factbound morass" $" 70$ indicates that there are factors surrounding the event in question that must be taken into consideration. Many of these factors, such as the severity of the crime and the immanency of harm to others, would carry over into an analysis of the use of force involving a drone. Yet, there are also new factors, such as the proximity of the officer and certain psychological factors like moral disengagement that could have a significant impact on future decisions.

\section{A. The Physical Location of the Officer}

Courts have cited the Supreme Court's statement in Graham, giving "allowance for the fact that police officers are often forced to make split-second judgments - in circumstances that are tense, uncertain, and rapidly evolvingabout the amount of force that is necessary in a particular situation," on over 2,300

\footnotetext{
${ }^{65} \mathrm{Id}$.

${ }^{66} \mathrm{Id}$.

${ }^{67}$ Rachel A. Harmon, When Is Police Violence Justified, 102 Nw. U. L. REV. 1119, 1140 (2008).

${ }^{68}$ Graham, 490 U.S. at 396.

${ }^{69}$ Harmon, supra note 67, at 1134-35.

${ }^{70}$ Scott, 127 S. Ct. at 1778.
}

USE OF FORCE AND WEAPONIZED POLICE DRONES

Volume XV - Spring 2015 • ISSN 2164-800X (online)

DOI 10.5195/tlp.2015.172 • http://tlp.law.pitt.edu 
occasions. ${ }^{71}$ Although this language is absent from the Court's decision in Scott, it is clear that courts throughout the country continue to rely on this language to determine whether or not an officer used "reasonable force." 72 Deference given to police in excessive force situations is often attributed to this language, and it serves as what courts and juries consider to be the inherent nature of police encounters. ${ }^{73}$

Drones could alter the way police encounters are viewed in very substantial ways. Perhaps most obvious, as stated previously, is the removal of an officer from the actual encounter, and instead replacing him or her with a drone operator potentially miles away from the scene. ${ }^{74}$ Not only does this fact eliminate an imminent threat to the safety of the drone operator, but it also eliminates several of the environmental factors that are taken into consideration when determining whether police force was reasonable. Research has shown that geographic area, the events leading up to the arrest, and the suspect's demeanor are factors that lead an officer to perceive a situation or suspect as dangerous. ${ }^{75}$ These factors elicit certain psychological responses, including stress and anxiety that affect that amount of force an officer uses. ${ }^{76}$ These factors are all taken into consideration when giving allowance to the split-second decisions officers make in "circumstances that are tense, uncertain, and rapidly evolving.,"77

Drones, by their very nature, eliminate the need for some of these factors to be taken into consideration. A drone operator is no longer in the environment, but is instead outside the environment of the actual police encounter. Drone operators are removed from direct contact with environmental factors that lead to the stress and anxiety that oftentimes results in the use of force, especially excessive force. ${ }^{78}$

${ }^{71}$ Stoughton, supra note 2, at 864-65.

${ }^{72}$ See Poole v. City of Shreveport, 691 F.3d 624 (5th Cir. 2012); Schoettle v. Jefferson County, Mo., 2014 WL 1117587 (E.D. Mo. 2014); Estate of Williams v. Indiana State Police, 26 F. Supp. 3d 824 (S.D. Ind. 2014).

${ }^{73}$ Stoughton, supra note 2, at 865; Harmon, supra note 67, at 1169.

74 All UAV Datasheets, UAV GLOBAL, http://www.uavglobal.com/shadowhawk/ (listing the Shadowhawk drone as having a range capability of up to 24 kilometers).

${ }^{75}$ See Geoffrey P. Albert \& William C. Smith, How Reasonable is the Reasonable Man? Police and Excessive Force, 85 J. CRIM. L. \& CRIMINOLOGY 481, 495 (1994) (describing how officers use of force depends on their environments); Robert E. Worden, The Causes of Police Brutality: Theory and Evidence of Police Use of Force, in Police Violence 23, 27 (William A, Geller \& Hans Toch eds., 1996) (describing how situational factors affect the use of police force).

${ }^{76}$ See generally Seth D. DuCharme, The Search for Reasonableness in Use-of-Force Cases: Understand the Effects of Stress on Perception and Performance, 70 FORDHAM L. REV. 2525 (2002).

${ }^{77} \mathrm{Id}$.

${ }^{78}$ Olsthoorn \& Royakkers, supra note 7.

Journal of Technology Law \& Policy

Volume XV - Spring 2015 • ISSN 2164-800X (online)

DOI 10.5195/tlp.2015.172 • http://tlp.law.pitt.edu 
Take for instance the shooting death of Amadou Diallo by New York City Police in 1999. Believing Diallo matched the description of a rape suspect, four NYPD officers approached him outside his dimly lit apartment building. ${ }^{79}$ Diallo retreated towards the apartment building, despite orders to stop, and reached into his jacket for his wallet. Believing he was reaching for a weapon, one of the officers yelled "Gun!" ${ }^{80}$ At that point, 41 shots were fired, 19 of which struck Diallo. ${ }^{81}$ No weapon was every found at the scene. ${ }^{82}$ After a jury trial, at which all four of the officers were acquitted, jury interviews revealed that a major consideration in their decision was figuring out how a reasonable officer would act in those circumstances, and relied on expert testimony describing an officer's perception of that type of situation. $^{83}$

It is possible in a situation such as the Diallo shooting that a drone in the place of an officer would change the dynamic. Jurors would not have to consider how an officer, seeing Diallo reach into his jacket pocket, would perceive the situation. Instead, the jurors would need to identify how a drone operator would perceive the events as they transpired, a question which is admittedly difficult to answer because this type of technology is not currently in use. However, removing the stress and anxiety associated with an imminent threat to officer safety could have a profound effect on the way judges and juries view an operator's actions.

\section{B. Moral Disengagement}

Although the use of drones may eliminate psychological stressors that lead to the use of excessive force, they may in turn add new psychological pressures that will have to be taken into consideration.

Over the course of their development, human beings develop certain "moral standards" that "serve as guides and deterrents for conduct." finding ways around these standards, and allowing oneself to carry out conduct contrary to them is known as moral disengagement. ${ }^{85}$ Researchers have put forth

\footnotetext{
${ }^{79}$ DuCharme, supra note 76, at 2533.

${ }^{80} \mathrm{Id}$.

${ }^{81} \mathrm{Id}$.

${ }^{82} \mathrm{Id}$.

${ }^{83}$ Id. at 2534.

${ }^{84}$ Albert Bandura, Moral Disengagement in the Perpetration of Inhumanities, 3 PERSONALITY \& SOC. PSYCHOL. REV. 193, 194, available at http://www.uky.edu/ eushe2/Bandura/Bandura1999PSPR .pdf.

${ }^{85}$ Id. at $193-94$.
}

USE OF F OR C E A N D W E A P O N I Z E P O L I C E D R O N E S

Volume XV - Spring 2015 • ISSN 2164-800X (online)

DOI 10.5195/tlp.2015.172 • http://tlp.law.pitt.edu 
many theories of what causes moral disengagement, but for drone purposes there are two theories that carry significant weight.

A "disregard or distortion of consequences" theory posits that if the results of harmful conduct are "ignored, minimized, distorted, or disbelieved," an individual's moral standards will not be activated. ${ }^{86}$ Normally, removing oneself from the results of the harmful conduct carries out this process. ${ }^{87}$ When a person can see and hear the pain they inflict upon another, their moral standards are more likely to act as self-restraints. ${ }^{88}$ The opposite is true when a person is removed from seeing or hearing the harm. In those instances, "even a high sense of personal responsibility is a weak restrainer of injurious conduct." 89

Drone use has the possibility to cause a "disregard or distortion of consequences." The theory suggests that when an individual is actually present and applying harm, their natural moral standards provide at least some type of restraint. ${ }^{90}$ However, a drone operator would not be present to apply the force and, although they would be able to see the subject, they may not have as great of a sense of the harm they are causing due to a lack of physical presence, making it easier to actually carry out harmful conduct. Removing the officer from the environment, and allowing him or her view the situation through a camera lens leads to another disengagement theory that may have an effect on drone operators.

The "dehumanization" theory suggests that "the joys and suffering of those with whom one identifies are more vicariously arousing than are those of strangers or of individuals who have been divested of human qualities." ${ }^{.91}$ By dehumanizing another person, one is viewing them as "subhuman objects," thus making unethical conduct more likely to occur. ${ }^{92}$ For drone purposes, this dehumanization theory has created significant concern, particularly in a military context where weaponized drones are prevalent. ${ }^{93}$ It has been suggested that showing "abstract images," such as those seen through a video camera, could dehumanize the enemy. ${ }^{94}$ Others have

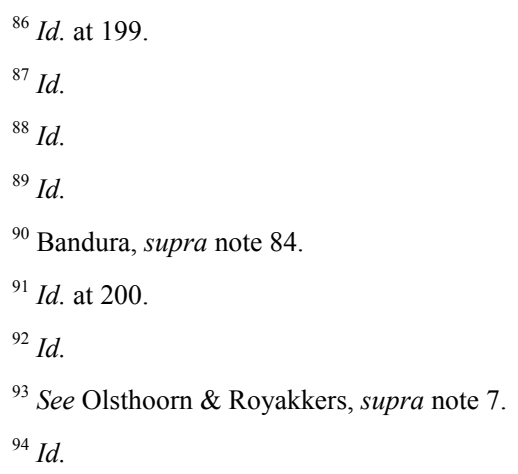

Journal of Technology Law \& Policy

Volume XV - Spring 2015 • ISSN 2164-800X (online) DOI 10.5195/tlp.2015.172 • http://tlp.law.pitt.edu 
stated that it could be difficult to differentiate the operating of a drone from playing a videogame, making the enemy or suspect more closely akin to an avatar in a game rather than another human being. ${ }^{95}$

Research on military drone use provides evidence for the assertion that the physical and psychological distance may make killing easier. ${ }^{96}$ As stated previously, without weaponized police drones in use it is difficult to determine what, if any, effect moral disengagement and physical distance would have on a police drone operator. Further, there appears to be no evidence that police drones would ever be equipped with the kind of lethal force used by the military. The fact remains, however, that physical and psychological distance could have an effect on the actions of drone operators and their decision to use force, making both vital factors for courts to consider in any future litigation.

\section{AN IMMINENT PUBLIC SAFETy STANDARD}

This Article has so far discussed what has become the traditional legal standard for the use of force by police, and how the introduction of an armed UAS could potentially change our traditional conception of these types of scenarios. The question now turns to how the traditional legal standard accounts for these technological changes.

It is unlikely that the Fourth Amendment's reasonableness standard is going to change at any time in the near future. ${ }^{97}$ This is not to say, however, that what the court is prepared to consider reasonable cannot change, and advancements in technology are often times causes for a shift in our notions of reasonableness. In fact, the Supreme Court in Garner explicitly stated that technological changes called for a shift in what was considered reasonable in regards to police use of force. ${ }^{98}$ Based on the changes discussed in this Article, the introduction of armed UAS should be a technological advancement that calls for a similar shift in what we consider reasonable force.

Reasonable use of force by police is based on the way judges and juries perceive what the officer in question is experiencing. The Graham opinion instructs courts to give allowance for the environments that police find themselves,

\footnotetext{
${ }^{95} \mathrm{Id}$.

${ }^{96} I d$. at 5.

${ }^{97}$ Scott, 127 S. Ct. at 1778.

${ }^{98}$ Garner, 471 U.S. at 8.
}

USE OF FORCE AND WEAPONIZED POLICE DRONES

Volume XV - Spring 2015 • ISSN 2164-800X (online)

DOI 10.5195/tlp.2015.172 • http://tlp.law.pitt.edu 
accounting for any imminent threats to the officer's safety. ${ }^{99}$ As was demonstrated in the Amadou Diallo case, juries form their own perceptions of what an officer goes through in these situations and hear expert witness testimony describing how environmental factors elicit certain responses and perceptions in these types of scenarios.

With these facts being known, would these uses of force still be reasonable when the officer is no longer physically experiencing the scenario? The fact that a UAS operator is not present necessarily means that the environmental factors affecting perceptions of the situation are absent. Taking away the consideration of these factors makes the use of force in many of these situations less than reasonable. This then gives rise to the question of how a court should determine whether a reasonable UAS operator would have applied a particular amount of force. To answer this question, it may be possible to simply adjust the guidance already provided by the Supreme Court. Of the suggestions put forth by the Court in Graham, the factor considering imminent threats to the officer's safety and the allowance given for environmental factors in general are not applicable to scenarios involving armed UAS. Removing these points allows the test only to consider the severity of the crime, threat of harm to others, and whether the suspect attempts to evade arrest. ${ }^{100}$ These three factors, in the aggregate, ask us to consider threats to public safety. The more severe the crime, the more dangerous a suspect may be to the public, and a suspect attempting to flee may pose further harm should he escape. Considering this point, the standard becomes one in which an armed UAS should only apply force where a reasonable drone operator would do so to prevent an imminent threat to public safety.

This is not a drastic departure from the current legal standard, and does not disturb the application of a reasonableness and totality of the circumstances approach of the Fourth Amendment. Yet, by narrowing the ability to actually use the force to circumstances involving imminent public harm, it may help to address some of the substantial differences that armed UAS create. The standard does not and would not give allowance for what an officer may perceive on the ground, ensuring that the court, when determining whether the application of force was reasonable, does not consider these perceptions. Doing this addresses the fact that an operator is not actually on the ground experiencing the events, and thus not susceptible to the same environmental factors. The court can then consider whether an operator who could be miles away could have reasonably recognized an imminent threat to public safety using factors such as the severity of the crime,

${ }^{99}$ Graham, 490 U.S. at 396.

${ }^{100} I d$.

Journal of Technology Law \& Policy

Volume XV - Spring 2015 • ISSN 2164-800X (online)

DOI 10.5195/tlp.2015.172 • http://tlp.law.pitt.edu 
evidence of a weapon, or if the suspect attempts to flee. This consideration is made easier by the existence of a video recording of the entire incident. Much like the situation in $S c o t t$, this allows the judge or jury to see exactly how the encounter transpired, allowing them to make some determination as to whether or not the application of force was reasonable.

This standard could also have some effect on preventing any moral disengagement concerns that may arise. As stated earlier, moral disengagement often occurs due to a distortion of consequences, causing a person to be detached from the harm they are causing to another. In a sense, causing the harm actually becomes easier for the person applying it. Allowing use of force by a UAS only in situations where there is an imminent threat to public safety may prevent this distortion by putting operators on alert that their actions may have serious consequences. Instead of being able to detach themselves from the harm, they would now be aware that the harm they cause can now have consequences on themselves if it is conducted outside the parameters of this standard.

The standard also preserves the totality of the circumstances approach so clearly applied in Garner, Graham, and Scott, while simultaneously addressing major changes that are brought about by the introduction of armed UAS. There are undoubtedly other factors that would need to be considered before any new standard is created, and until this technology is actually put to use it is nearly impossible to determine what unforeseen issues may arise. With these facts in mind, this standard provides a simple starting point for the courts to use, preserving precedent and legal history while concurrently allowing for adjustment to a new technology that could significantly affect the landscape.

\section{CONCLUSION}

There are certainly aspects of this type of technology that are not contemplated in this Article. The manner in which the technology is deployed, the system's degree of autonomy, and the capabilities of the weaponry are all factors that could significantly alter any analysis on this issue. The purpose of this Article is to demonstrate how the introduction of armed UAS could substantially change the analysis of an excessive force claim and propose a solution to address these changes. Allowing the use of force only where a reasonable drone operator would recognize an imminent public danger addresses both the absence of the officer from the scene and possibly offset at least some of any moral disengagement problems.

Until further research is conducted concerning the issues that these drones could present followed by their actual deployment in the field, it will remain difficult to determine how the courts will handle these situations. It is important, 
however, that we begin to contemplate the challenges this new technology may pose and how our legal system will address them in the future. 